\title{
COVID-19: impact by and on the environment, health and economy
}

\author{
Sneha Gautam ${ }^{1} \cdot$ Luc Hens $^{2,3}$
}

๑) Springer Nature B.V. 2020

\section{Call for manuscripts}

COVID-19 is now recognized as the one of the most tempting challenges and largest tragedy of the century after the Second World War (Gautam 2020a). A novel respiratory disease has been reported in late December 2019 in Wuhan a city of the Hubei Province of China, and its now underlined by WHO (World Health Organization) as coronavirus disease-2019 (COVID-19) (WHO 2020; Gautam and Hens 2020). The classification of novel coronavirus (i.e., large in number, single-stranded ribonucleic acid virus of the subfamily Orthocoronavirinae, family Coronaviridae order Nidovirales), which is now separated in alpha, beta, delta and gamma alpha and beta coronavirus among these four, are associated with human health issues (Peters et al. 2020). During human history, a number of outbreaks of viral epidemic diseases have been reported (Gautam and Trivedi 2020). On June 1, 2020, there were worldwide 372,035 deaths, and 6,166,946 confirmed cases of Coronavirus infections (https://aajtak.intoday.in/). Many countries reported developing antiviral drugs or vaccines to control COVID-19; however, a single clinically approved treatment could not be found. On the other hand, the entire world population currently faces enormous challenges (i.e., social, environmental, health, and economic) due to impact of COVID-19 (Gautam 2020b). In this regard, the affected countries are now trying to slow down of the transmission of the virus by self-distancing, strategies of lockdowns, increasing the number of testing and treatment and restricting large gatherings.

Until now most attention in the literature was paid to the medical aspects of the pandemic. As in many countries the (first) peak of the infections and the hospital admissions is over, the attention moves towards the social, economic and sustainability impacts. They contribute to an in depth assessment of how the epidemic was dealt with, and the lessons learned for the future.

In this context, Environmental Development and Sustainability is now open to research contributions on the reported challenges (i.e., social, environmental, health, and economic) due to COVID-19. The special issue which is planned is less targeted to the medical/

Luc Hens

luchens51@gmail.com

1 Karunya Institute of Technology and Sciences, Coimbatore, Tamil Nadu 641114, India

2 Vlaamse Instelling voor Technologisch Onderzoek, Boeretang, Mol 2400, Belgium

3 Department of Economics, Sumy State University, Sumy, Ukraine 
virology aspects of the pandemic but merely to original research results of the economic (how to restore economies after the lockdowns), social (the uneven spread of the infections over social groups-poverty) and the environmental (impact of air pollution and meteorological characteristics on the infections caused the virus) aspects. It is imperative analyzing the consequences of this sustainability analysis, both at the short and the long term. The purpose of this issue is to call for scientific original papers on the role that the environment could play in transmission, pathogenesis, and severity of COVID-19 and/or its related mortality. Moreover, the aim is to also reviewing the interaction between this pandemic and sustainability and planetary health, including climate change, biodiversity, and urban built environment. Reviews on the lessons of the current pandemic for long-term sustainability, urban built environment, and planetary health are also invited.

\section{References}

Gautam, S. (2020a). The influence of COVID-19 on air quality in India: A boon or inutile. Bulletin of Environmental Contamination and Toxicology. https://doi.org/10.1007/s00128-020-02877-y.

Gautam, S. (2020b). COVID-19: Air pollution remains low as people stay at home. Air Quality, Atmosphere and Health. https://doi.org/10.1007/s11869-020-00842-6.

Gautam, S., \& Hens, L. (2020). SARS-CoV-2 pandemic in India: What might we expect? Environment, Development and Sustainability, 22, 3867-3869.

Gautam, S., \& Trivedi, U. K. (2020). Global implication of bioaerosol in pandemic. Environment, Development and Sustainability, 22, 3861-3865.

Peters, A., Vetter, P., Guitart, C., Lotfinejad, N., \& Pittet, D. (2020). Understanding the emerging coronavirus: What it means for health security and infection prevention. Journal of Hospital Infection. https:// doi.org/10.1016/j.jhin.2020.02.023.

World Health Organization. (2020). Coronavirus disease (COVID-2019) situation reports. Geneva: World Health Organization. Retrieved March 23, 2020 from https://www.who.int/emergencies/diseases/novel -coronavirus-2019/situation-reports/. Opens in new tab.

Publisher's Note Springer Nature remains neutral with regard to jurisdictional claims in published maps and institutional affiliations. 